Alen Lalić, mag. iur. ${ }^{1}$

Ivan Rančić, mag. iur. ${ }^{2}$

\title{
GRUBA NEZAHVALNOST KAO RAZLOG OPOZIVA UGOVORA O DAROVANJU
}

Stručni rad / Professional paper UDK / UDC 347.447.93:347.472

DOI: $10.51650 /$ ezrvs.15.1-2.8

Primljeno / Received: 27/5/2021

Prihvaćeno / Accepted: 21/6/2021

Ugovori koji ne sadrže nikakve nedostatke, i u cijelosti su ispunjeni, u praksi rijetko kada mogu prestati, a sve zbog građansko pravnog principa da je ugovor zakonom uređen odnos među strankama. Ugovor o darovanju predstavlja iznimku, jer isti može prestati putem instituta opoziva darovanja, iako ne sadrži nikakav nedostatak, i u cijelosti je ispunjen. Besplatnost darovnog ugovora razlog je zbog kojeg zakonodavac omogućava prestanak ispunjenog i punovažnog ugovora o darovanju. Zakon o obveznim odnosima poznaje dva razloga opoziva koji počivaju ili na činjenici da su se materijalne okolnosti na strani darovatelja naknadno toliko promijenile da je ugrožena materijalna egzistencija darovatelja, ili na činjenici da je druga strana kriva za prestanak ugovora. Krivnja druge strane odnosno obdarenika ne odnosi se na krivnju glede samog sadržaja ugovora o darovanju i njegovog ispunjena, jer je ugovor uredno ispunjen. Moralno je da je obdarenik zahvalan za učinjeno darovanje, i da ne poduzima radnje prema darovatelju koji bi dovele do bitnog narušavanja međusobnih odnosa. Međutim, isti obdarenik zaboravlja svoju „moralnu obvezu", te se nakon učinjenog darovanja počinje ponašati na grub i nemoralan način prema darovatelju. Upravo je zbog toga omogućeno darovatelju da putem instituta opoziva zbog grube nezahvalnosti opozove ugovor o darovanju, a što traži i sam zahtjev pravičnost, iako je ugovor ispunjen, jer je nemoralno da takav obdarenik zadrži ono što je dobio besplatno od strane darovatelja. Cilj predmetnog rada je da razradi pojam opoziva darovanja zbog grube nezahvalnosti prema odredbama aktualnog Zakona o obveznim odnosima. Predmetni rad će i razraditi poimanje grube nezahvalnosti prema pravnim pravilima OGZ-a a sve sobzirom da su ista pravila (i dalje) mjerodavna za one darovne ugovorne odnose koje su nastale prije stupanja na snagu aktualnog Zakona o obveznim odnosima.

Ključne riječi: ugovor o darovanju, opoziv darovanja, gruba nezahvalnost.

\footnotetext{
1 Veleučilište u Šibeniku, e-mail: alalic@vus.hr

${ }^{2}$ Veleučilište u Šibeniku, e-mail: irancic@vus.hr
} 


\section{Uvod}

Današnja uglavnom kapitalistička poimanja društvenih, a i građansko pravnih odnosa počivaju na principu da je za svaku danu stvar ili učinjenu uslugu potrebno izvršiti protuuslugu, ili drugoj strani dati odgovarajuću stvar jednake protuvrijednosti. Ugovor o darovanju predstavlja iznimku, jer isti ima za cilj prijenos pojedinih dijelova imovine, pojedinih stvari, a ponekad i čitave imovine sa darovatelja na obdarenika bez ikakve protuusluge odbdarenika. Obdarenik iako ima odgovarajuće obligacije prema darovatelju i/ili trećima, takva "obveza" je u očiglednom svjesnom nesrazmjeru sa onim što je darovatelj dao obdareniku.

Motiv sklapanja ugovora o darovanju često počiva na nekoj vrsti emocionalne povezanosti darovatelja prema obdareniku, kojim zbog te emocionalne povezanosti darovatelj želi prenijeti na obdarenika vrlo često i vrjedniji dio svoje imovine, ili čak čitavu svoju imovinu bez da nešto traži za uzvrat. Ta emocionalna povezanost može biti posljedica nekih obiteljskih odnosa (npr. roditelja prema djeci i obrnuto, djeda i bake prema svojim unucima i obrnuto, braće prema sestrama i obrnuto, itd.), partnerskih odnosa( bračnih supružnika, izvanbračnih supružnika, partnera $u$ istospolnoj zajednici) ili su posljedica nekog dobrog ponašanja obdarenika prema darovatelja (npr. obdarenik se brine o darovatelju iako nema zakonsku ili ugovornu obvezu, te nije srodnik darovatelju), a koja povezanost kod darovatelja stvara zaključak da je pravedno da "obdari" obdarenika svojom imovinom. Upravo su i ugovori o darovanju u pravilu "intutite persone" ugovori gdje je naglasak na samome obdareniku i njegovoj vezi sa darovateljem. Obdarenik s druge strane, u pravilu prima predmetne darove sa zahvalnošću, te isti dobiva osnovu za stjecanja prava vlasništva na imovini ili stvarima darovatelja.

Međutim, životno iskustvo nam često govori da ona emocionalna povezanost koja je postojala kod darovatelja može naknadno otpasti. Razlog takvom „otpadanju“ često se pronalazi u naknadnom postupanju samog obdarenika. Obdarenik zaboravlja učinjeno darovanje, te postupa prema darovatelju ili njemu bliskim osobama na grub, nepristojan, nemoralan, a ponekad i kažnjivi način, a koja ponašanja se mogu okarakterizirati kao nezahvalnost obdarenika za ranije učinjeno darovanje.

Upravo iz ranije navedenog razloga predviđena je mogućnost prestanaka punovažnog ugovora o darovanju putem instituta opoziva darovanja zbog grube nezahvalnosti obdarenika. Predmetni opoziv predstavlja iznimku od temeljnog načela ugovornih odnosa da je ugovor "zakon među strankama". Dakle, iako ugovor o darovanju ne sadrži nikakve nedostatke i uredno je ispunjen, isti može prestati putem instituta opoziva ugovora.

Unatoč tome što se ugovori o darovanju često sklapaju na području Republike Hrvatske, kao i činjenice da se isti često pred sudovima Republike Hrvatske pokušavaju opozvati zbog grube nezahvalnosti, predmetni opoziv darovanja nije pobudio značajniji pravni interes naše pravne književnosti.

Cilj predmetnog rada je da se kroz prizmu sudske prakse (i drugih pravnih izvora) napravi presjek opoziva zbog grube nezahvalnosti u domaćem pravu, te pokuša odgovoriti na pitanja kao što su: što predstavlja i što je predstavljala gruba nezahvalnost? Koja je granica između nekulturnog ili nezahvalnog ponašanja s jedne strane, u odnosu na (krajnju) grubu nezahvalnost s druge strane? Je li za postojanje grube nezahvalnosti potrebno da takva radnja ostvaruje (uvijek) obilježje kažnjivog djela? Mogu li se pojedini oblici ponašanja obdarenika standardizirati kao gruba nezahvalnost u svim drugim istovjetnim slučajevima, ili 
procjena postajanja grube nezahvalnosti obdarenika prema darovatelju u potpunosti ovisi o okolnostima konkretnog slučaja? Cilj predmetnog rada je i razraditi poimanje grube nezahvalnosti prema ranijim pravnim pravilima, a koji su i dalje mjerodavni za one ugovorne odnose koji su nastali prije stupanja na snagu aktualnog Zakona o obveznim odnosima.

\section{Pojam i pravna regulacija ugovora o darovanju}

U hrvatskoj pravnoj teoriji nema značajnih dvojbi oko toga što bi trebao predstavljati ugovor o darovanju. Tako Pravni leksikon (2007, str. 1651) definira Ugovor o darovanju kao „ugovor kojim se darovatelj obvezuje prepustiti obdareniku besplatno (bez protučinidbe), stvar ili imovinsko pravo." Nadalje, Vedriš i Klarić (2009, str. 507) definiraju ugovor o darovanju gotovo na identičan način i to kao „ugovor kojim jedna strana (darovatelj), dobrovoljno i besplatno prepušta drugoj strani (obdarenik) neku imovinsku korist, a ovaj to prihvaća."

Nadalje, ne postojanje dvojbe u hrvatskoj pravnoj književnosti oko poimanja što bi predstavljao ugovor o darovanju proizlazi iz činjenice da je isti ugovor sadržajno definiran i u aktualnim zakonskim odredbama.

Ugovor o darovanju reguliran je odredbama čl. 479. - 498. Zakona o obveznim odnosima3 koji u svom prvom članku namijenjenom ugovoru o darovanju definira trenutak nastanka ugovora o darovanju, te navodi da ugovor nastaje kada se darovatelj obveže prepustiti obdareniku bez protučinidbe stvar ili imovinsko pravo, a obdarenik to prihvati. Iz predmetne odredbe vidljivo je da je naglasak stavljen na činjenicu da se radi o ugovornom odnosu u kojom se jedna strana obvezuje prepustiti određenu stvar ili imovinsko pravo, a druga strana pristaje prihvatiti namjeru darovanja. Isto tako u predmetnoj zakonskoj definiciji naglasak je stavljen i na besplatnost pravnog posla, jer se sam darovatelj obvezuje prepustiti stvar ili imovinsko pravo bez protučinidbe. Međutim, ipak postoji mogućnost, a što je vidljivo u kasnijim odredbama Zakona o obveznim odnosima (Ugovor o darovanju s nametom regulirano odredbama čl. 484-487 ZOO-a) da obdarenik ima odgovarajuću „obvezu“ prema darovatelju ili trećima, ali takva obveza je u očiglednom svjesnom nesrazmjeru sa onim što se darovatelj obvezao dati na ime ugovora o darovanju i gdje postoji motiv darovatelja da na taj način obdari obdarenika.

Od trenutka stupanja na snagu izvornog teksta Zakona o obveznim odnosima (01.siječnja 2006.godine) pa do današnjeg dana, Zakon o obveznim odnosima imao je tri izmjene i/ili dopune izvornog teksta samog Zakona. ${ }^{4}$ Zakonodavac u odjeljku Ugovora o darovanju nije vršio nikakve izmjene ili dopune odredbi Ugovora, što proizlazi iz činjenice da se i današnji

\footnotetext{
${ }^{3}$ Narodne novine br. 35/05, 41/08, 125/11, 78/15, 29/18; u daljnjem tekstu: ZOO

4 Zakon o izmjenama i dopunama Zakona o obveznim odnosima br. NN 41/2008 koji je stupio na snagu 17.travnja 2008.godine, Zakon o izmjenama i dopunama Zakona o obveznim 78/15 koji je stupio na snagu 1. kolovoza 2015. godine i Zakon o izmjenama i dopunama 29/2018.godine koji je stupio na snagu 1.srpnja 2018.godine. Međutim, Zakon o obveznim odnosima je imao u stvarnosti četiri izmjene izvornog teksta Zakona. Naime, 26.listopada 2011. godine proglašen je posebni Zakon i to Zakon o rokovima ispunjena novčanih obveza br. NN 125/11 a koji je stupio na snagu 01.siječnja 2012.godine. Predmetnim Zakonom uređeni su rokovi ispunjena novčanih obveza i pravne posljedice zakašnjenja novčanih obveza. Ono što je bitno za sam Zakon o obveznim odnosima jest da je u svojim prijelaznim i završnim odredbama Zakona o rokovima ispunjena novčanih obveza i to u čl.9. odredio da stupanjem na snagu predmetnog Zakona prestaje važiti odredba čl. 174. Zakon o obveznim odnosima (Narodne novine br. 35/05. i 41/08.) tj. odredbe koje je ranije regulirala rok ispunjena novčanih obveza kod trgovačkih ugovora.
} 
ugovor o darovanju razvio iz rimskog prava (donatio) i to kao „besplatne i dobrovoljne namjene prijenosa koristi kojom se povećava imovina obdarenika, a umanjuje imovina darovatelja" (Belanić i dr., 2012., str. 117), a koji ugovor tijekom svoje povijesti nije imao nikakve značajne izmjene pogotovo glede samog sadržaja ugovora.

Zanimljivo je da Zakon koji je ranije regulirao obvezno pravne odnose na području Republike Hrvatske, i to Zakon o obveznim odnosima iz 1978.godine ${ }^{5}$ nije sadržavao odredbe ugovora o darovanju. Razlog počiva u tome što se „smatralo da ugovor o darovanju nije tipičan pravni instrument prometa roba i usluga, a tadašnja federacija je - prema Ustavu SFRJ iz 1974. - imala samo ovlast reguliranja robnog prometa, pri čemu Republička zakonodavstva (pa tako ni Hrvatska) nisu koristila ustavne mogućnosti donošenja vlastitih propisa u ovoj materiji“ (Belanić i dr., 2012., str. 118). Zakon o obveznim odnosima iz 1978. godine preuzet je u pravni poredak samostalne i neovisne Republike Hrvatske donošenjem posebnog Zakona, i to Zakona o preuzimanju Zakona o obveznim odnosima. ${ }^{6}$ Zakonodavac je vodio računa o tome da se reguliraju i ugovorni odnosi darovanja, pa je u članku 27. Zakona o preuzimanju ZOO 78 izričito predvidio da će se paragrafi Općeg građanskog zakonika7 kao pravna pravila primjenjivati na darovanja i ortakluk. Međutim, pogrešan bi bio zaključak da darovanje nije bilo regulirano na području Republike Hrvatske prije donošenja Zakona o preuzimanju ZOO '78.

Naime, nakon II. svjetskog rata donesen je Zakon o nevažnosti pravnih propisa donesenih prije 06. travnja 1941. godine i u vrijeme neprijateljske okupacije. ${ }^{8}$ Taj Zakon je propisao da se pod određenim uvjetima kao pravna pravila mogu primjenjivati i propisi doneseni do 06. travnja 1941.godine, a ti uvjeti su u svojoj suštini, kao prvo, da neko područje nije uređeno propisima nove države i njezinih sastavnica, a niti u suprotnosti s načelima socijalističkog pravnog poretka kao temeljnom političkom, odnosno vrijednosnom odrednicom nove države. Na taj način Opći građanski zakonik se primjenjivao sukladno ovim ograničenjima bez ikakvih pauza za cijelo vrijeme postojanja „bivše države“ (Belanić i dr., 2012).

Razlog zašto je bitno prikazati način na koje se ranije regulirao obvezno pravni odnos povodom ugovora o darovanju počiva u samim prijelaznim i završnim odredbama važećeg Zakona o obveznim odnosima. Naime, u čl. 1163. st. 1. ZOO-a izričito je propisano da se odredbe tog Zakona neće primjenjivati na one obvezno pravno odnose koje su nastali prije stupanja na snagu samog Zakona o obveznim odnosima. Dakle, iz predmetne odredbe proizlazi da je za one ugovorne odnose koje su nastali prije 01. siječnja 2006. godine mjerodavno pravo koje je bilo na snazi u trenutku nastanka tih ugovornih odnosa. Kako je predmet ovog rada Ugovor o darovanju i to njegov opoziv zbog grube nezahvalnosti za predmetne obvezno pravne odnose prije 01.siječnja 2006. godine, mjerodavna su pravna pravila Općeg građanskog Zakona.

U predmetnom radu bitno je istaknuti, da bi pogrešan zaključak bio da Zakon o obveznim odnosima iz 1978. godine nije na bilo koji način bio mjerodavan za ugovore o darovanju koji su

\footnotetext{
${ }^{5}$ Zakon o obveznim odnosima (Službeni list SFRJ br. 29/1978, 39/1985, 46/1985, 57/1989, u daljnjem tekstu ZOO 78 ili Zakon o obveznim odnosima iz 1978.godine)

${ }^{6}$ Zakon o preuzimanju Zakona o obveznim odnosima (Narodne novine 53/91); u daljnjem tekstu: Zakon o preuzimanju ZOO 78.

7 Allgemenies Burgerliches Gesetzbuch (ABGB) ili Opći Građanski zakonik (u daljnjem tekstu: Opći građanski Zakonik ili OGZ).

${ }^{8}$ Zakon o nevažnosti pravnih propisa donesenih prije 06.travnja 1941.godine i u vrijeme neprijateljske okupacije (SL. 1. FNRJ br.86/46)
} 
sklopljeni u trenutku njegovog važenja. Naime, predmetni Zakon sadržavao je opće odredbe ugovornog prava koje su se primjenjivale na sve ugovorne odnose, pa tako i na ugovor o darovanju. ${ }^{9}$

Međutim, Zakon o obveznim odnosima nije jedini aktualni Zakon koji sadrži odredbe koje su mjerodavne za ugovor o darovanju. Sigurno najznačajniji je Zakon o vlasništvu i drugim stvarnim pravima ${ }^{10}$ koji među ostalim regulira i pretpostavke radi stjecanja prava vlasništva na temelju pravnog posla u čl. 115. - 129., a s obzirom da je „causa“ ugovora o darovanju kao jednog pravnog posla stjecanje prava vlasništva. U tom smislu čest je pogrešan zaključak da se sklapanjem ugovora o darovanju stječe pravo vlasništva na predmetu darovanja. Upravo uzimajući odredbe čl. 116., 120., i 121. Zakona o vlasništvu proizlazi da je za stjecanje prava vlasništva na temelju pravnog posla (a time i ugovora o darovanju) potrebno ne samo da se sklopi ugovor o darovanju, već i da se izvrši predaja u samostalni posjed pokretnine, odnosno da se izvrši uknjižbi prava vlasništva na nekretnini na temelju pravnog posla. Posebno ovo potonje stvara probleme kada obdarenici smatraju da su postali vlasnici nekretnine sklapanjem ugovora o darovanju, iako nisu nikada na temelju takvog ugovora o darovanju ishodili uknjižbu prava vlasništva. ${ }^{11}$

Nadalje, za ugovor o darovanju mjerodavne su i odredbe Obiteljskog Zakona ${ }^{12}$ koje reguliraju ograničenja roditelja povodom raspolaganja imovinom djeteta koja je djetetu darovana, ili je istu naslijedio (čl. 98. OBZ-a), kao i zastupanja u vezi s vrjednijom imovinom djeteta (čl. 101. OBZ-a). Nastavno na navedeno Zakon koji je ranije regulirao obiteljsko pravne odnose (u razdoblju od 1.siječnja 1979. godine do 30. lipnja 1999. godine), i to Zakon o braku i porodičnim odnosima $^{13}$ sadržavao je odredbe kojima je bila predviđena mogućnost opoziva učinjenih darova među bračnim supružnicima nakon prestanka ili poništenja braka pod određenim pretpostavkama ${ }^{14}$ i to u roku od jedne godine od prestanka braka (čl. 291.st.3. ZBPO-a).

Zakon o javnom bilježništvu ${ }^{15}$ također sadrži odredbe mjerodavne za ugovor o darovanje,

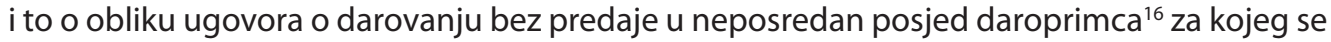
zahtjeva da se sklopi u obliku javnog bilježničkog akta (čl. 53. st. 1. ZJB-a). Predmetni rad se

\footnotetext{
${ }_{9}$ Vrhovni sud Republike Hrvatske u odluci br. Rev-1259/90-2, od dana 10.listopada 1990. godine: „....na ovaj ugovor valja primijeniti i odredbe općeg dijela ZOO koje imaju opći karakter za sve ugovore, kao i one koji se odnose na ugovore bez naknade (član 103, član 111. ZOO idrugi)..."

10 Zakon o vlasništvu i drugim stvarnim pravima (Narodne novine br. 91/96, 68/1998, 137/1999, 22/2000, 73/2000, 114/2001, 79/2006, 141/2006, 146/2008, 38/2009, 153/2009, 90/2010, 143/2012, 152/2014 u daljnjem tekstu Zakon o vlasništvu ili ZV)

11 Vrhovni sud Republike Hrvatske u odluci br. Rev-x 737/11-2 od dana 04.rujna 2012.godine :„....Polazeći od utvrđenja da tužiteljica nije na temelju ugovora o darovanju ishodila uknjižbu prava suvlasništva na predmetnoj nekretnini, te da nije dokazala ni neki drugi odgovarajući način stjecanja prava vlasništva a bez uknjižbe u zemljišnim knjigama, pravilno su nižestupanjski sudovi odbili tužbeni zahtjev za utvrđenje prava vlasništva...."

12 Obiteljski zakon (Narodne novine br. 103/15, 98/19, u daljnjem tekstu OBZ ili Obiteljski zakon)

13 Zakon o braku i porodičnim odnosima (Narodne novine br. 11/78, 27/1978, 45/89, 25/94, 162/98 u daljnjem tekstu Zakon o braku i porodičnim odnosima ili ZBPO)

${ }_{14}$ Čl.291. st.2. ZBPO- a; „Darovi iz posebne imovine bračnog druga, koji su nerazmjerno velike vrijednosti u odnosu na vrijednost njegove cjelokupne imovine u vrijeme postavljanja zahtjeva za vraćanje, vraćaju se darodavcu u slučaju razvoda ili poništenja braka. Takav dar nije dužan vratiti bračni drug koji bi vraćanjem dara došao u teške materijalne prilike."

15 Zakon o javnom bilježništvu (Narodne novine 78/93, 29/94, 162/98, 16/07, 75/09, 120/16, u daljnjem tekstu ZJB ili Zakonom o javnom bilježništvu)

${ }^{16}$ U hrvatskoj pravnoj književnosti, u sudskim odlukama kao i pravnim propisima Republike Hrvatske često se umjesto pojma "obdarenik" (kako se poima u Zakonu o obveznim odnosima) koristi istovjetan pojam "daroprimac" kao što je vidljivo u Zakonu o Javnom bilježništvu.
} 
neće baviti drugim odredbama Ugovora o darovanju koje su propisane Zakonom o obveznim odnosima, Zakonom o obveznim odnosima iz 1978. godine kao i drugim odredbama Općeg građanskog Zakonika, već isključivo opozivom darovanja, i to zbog grube nezahvalnosti obdarenika prema OGZ-u i ZOO-u. ${ }^{17}$

\section{Opoziv darovanja- razlozi i opća pravila}

\subsection{Razlozi i opća pravila za opoziv darovanja prema OGZ-u}

Kako su zbog prijelaznih i završnih odredbi Zakona o obveznim odnosima za ugovorno pravne odnose koji su nastali prije stupanja na snagu predmetnog zakona mjerodavni raniji propisi koji su bili na snazi, u konkretnom slučaju potrebno je i navesti i one koje Opći građanski zakonik predviđa kao razloge za opoziv darovanja kao i opća pravila koja su svojstvenima svim razlozima opoziva.

Pravnim pravilima OGZ-a propisano je šest razloga opoziva darovanja i to: opoziv radi oskudnosti (Paragraf 947 OGZ-a), radi neharnosti (Paragraf 948- 949 OGZ-a), radi oštećenja dužnog uzdržavanja (Paragraf 950 OGZ-a), radi oštećenja zakonitog djela (Paragraf 951-952 OGZ-a), radi oštećenja vjerovnika (Paragraf 953 OGZ-a) i poslije rođene djece (Paragraf 954 OGZ-a). Predmetni rad se neće baviti drugim razlozima opoziva darovanja prema OGZ-u već isključivo opozivom darovanja zbog nezahvalnosti (neharnosti).

Zanimljivo je da za razliku od ZOO-a, OGZ ne sadrži nikakva opća pravila koja su svojstvena svim razlozima radi opoziva darovanja. Zajedničko svim ugovorima o darovanju da se isti mogu „poreći“ jedino ukoliko postoji neki od ranije navedenih šest razloga (Paragraf 946 OGZ-a). Pojam poreći bi trebalo u duhu današnjeg (pravnog) rječnika tumačiti pravom na sudski raskid ugovora o darovanju. Dakle, sud je taj koji je na temelju tužbenog zahtjeva raskidao ugovor o darovanju ukoliko bi utvrdio postojanje jedan od razloga radi opoziva darovanju. Ono što je i pitanje da li postoji zastrani rok u kojem bi darovatelj bio dužan podnijeti tužbu radi opoziva darovanja. Pregledom odredbi o razlozima radi opoziva darovanja bi se stvorio zaključak da takvo pravo ne zastarijeva. Međutim, pregledom drugih odredbi OGZ-a i to posebnih odredbi o zastari, vidljivo je da je OGZ predvidio trogodišnji rok u kojem tužitelj može tražiti opoziv darovanja (Paragraf 1487 OGZ-a). Iz odredbe o trogodišnjem roku OGZ-a nije vidljivo da li je predmetni rok subjektivan ili objektivan odnosno da li se rok računa od vremena saznanja darovatelja (tužitelja) za okolnost radi opoziva darovanja ili se predmetni rok računa od momenta nastupa okolnosti neovisno o saznanju darovatelja. Pregledom sudske prakse vidljivo je da Vrhovni sud Republike Hrvatske zauzeo stav da se radi o subjektivnom roku ${ }^{18}$ što je i logično jer bi suprotno tumačenje dovelo do zaključka da darovatelju može otpasti razlog radi opoziva darovanja jer isti nije imao pojma da se takva okolnost dogodila.

\footnotetext{
17 O drugim odredbama Ugovora o darovanju pogledati: Klarić P., Vedriš M.(2009), Građansko pravo, Narodne novine, Zagreb,. str. 507-510., Belanić L., Gorenc V., Kačer H., Momčinović H., Slakoper Z., Vukmir B. (2012), Obvezno pravo, posebni dio l., pojedini ugovori, Novi informator, Zagreb str.115- str.137., Crnić I(2002), Zakon o obveznim odnosima s opsežnom sudskom praksom, Organizator, Zagreb, 924-937 str.

18 Vrhovni sud Republike Hrvatske u odluci u predmetu posl.br. Rev 816/10-2 od dana 27.lipnja 2012.godine:"... Prema odredbi paragrafa 1487. OGZ tužba za opoziv darovanja zastarijeva u roku od tri godine. Tužitelj je za razlog za opoziv darovanja saznao 2002., kada je podnio kaznenu prijavu protiv tuženice (list 16), pa do podnošenja tužbe u ovoj pravnoj stvari (10. travnja 2003.) nije proteklo propisano vrijeme zastarijevanja..."
} 


\subsection{Razlozi i opća pravila za opoziv darovanja prema ZOO-u}

Zakon o obveznim odnosima poznaje dva razloga opoziva darovanja, $i$ to pored opoziva zbog grube nezahvalnosti postoji i mogućnost opoziva darovanja zbog osiromašenja darovatelja (čl. 494. ZOO-a). Zakonodavac je vodio računa i o tome da se darovanjem mogu ugroziti obveze uzdržavanja darovatelja prema trećim osobama, pa je i u tom slučaju predvidio mogućnost da ista treća uzdržavana osoba traži od obdarenika nadopunu uzdržavanja onoga što zbog učinjenog darovanja darovatelj više nije u stanju činiti (čl.495. ZOO-a). Naravno uvijek postoji mogućnost da su pojedinim posebnim Zakonom predviđeni neki drugi razlozi zbog kojih može prestati punovažni ispunjen ugovor o darovanju. Najznačajnije su odredbe Zakona o nasljeđivanju ${ }^{19}$ koje predviđaju mogućnost vraćanje darova ukoliko je učinjenim darovanjem povrijeđen nužni nasljedni dio nužnog nasljednika (čl.78. ZN-a). Pored činjenice da darovatelj svojim darovanjem može „izigrati“ osobu koju je dužan uzdržavati kao i nužnog nasljednika, isti sklapanjem ugovora o darovanju može „izigrati“ i svog vjerovnika time što ga pokuša onemogućiti u naplati njegovog potraživanja. Upravo zbog tog razloga Zakon o obveznim o odnosima predvidio je i mogućnost pobijanja vjerovnikovih pravnih radnji (u našem slučaju darovanja) ukoliko je ista radnja počinjena na štetu vjerovnika (čl. 66-71. ZOO-a). Kao što je ranije navedeno predmetni rad će se baviti isključivo pitanjem opoziva darovanja zbog grube nezahvalnosti.

Zakon o obveznim odnosima sadrži i opća pravila koja su mjerodavna za sve vrste opoziva darovanja, a koja su regulirana odredbama čl.496. - 498. predmetnog Zakona.

Glede općih pravila opoziva darovanja aktualnog Zakona o obveznim odnosima isti sadrži odredbe o roku u kojem se može tražiti opoziv, te odredbe o obliku i učinku opoziva. Zakon predviđa jednogodišnji rok radi opoziva darovanja, a koji počinje teći od trenutka saznanja darovatelja za razlog opoziva, osim ukoliko ZOO-om ili nekim drugim zakonom nije propisan drugačiji rok (čl. 497. ZOO-a). Očigledno je da se radi o subjektivnom roku kojim protekom dolazi o prekluzije prava na opoziv darovanja (Belanić i dr., 2012, str. 135). Međutim, opća pravila ZOO-a ne sadrže objektivan rok, kao niti posebna pravila ZOO-a o opozivu darovanja zbog grube nezahvalnosti, za razliku od primjerice (posebne) odredbe opoziva zbog osiromašenja koji predviđa petogodišnji rok za pokretnine, odnosno desetogodišnji rok za nekretnine (čl.493. st.4. ZOO-a). Nepostojanje objektivnog roka za opoziv darovanja zbog grube nezahvalnosti s jedne stvara pravnu nesigurnost jer svaki ugovor može prestati neovisno o vremenu kada je isti sklopljen. Opet, s druge strane obvezuje obdarenika da se ne ponaša na grub način prema darovatelju jer uvijek postoji opasnost da zbog suprotnog ponašanja izgubi ono što je stekao predmetnim ugovorom o darovanju.

Opoziv darovanja daje se pisanom izjavom darovatelja koja je upućena obdareniku (čl.496.st.1. ZOO-a), a u kojoj izjavi potpis darovatelja mora biti ovjeren od strane javnog bilježnika (čl.496.st.2. ZOO-a). Očigledno je da se upućivanjem predmetne izjave raskida i prestaje sam ugovor o darovanju. ${ }^{20} \mathrm{Da}$ je tome tako vidljivo je i iz slijedeće zakonske odredbe,

19 Zakon o nasljeđivanju (Narodne novine br. 48/2003, 163/2003, 35/2005, 127/2013, 33/2015, 14/2019, u daljnjem tekstu Zakon o nasljeđivanju ili ZN)

20 Što bi predstavljalo upućivanje u zakonskoj odredbi o opoziva darovanja može se izvući iz odluke Županijskog suda u Bjelovaru u predmetu posl.br. Gž-2391/2012, od dana 6.veljače 2014.godine kada navodi: ,...Za sprječavanje nastupa prekluzije opoziva ugovora o darovanju nije relevantno vrijeme sastava ovjere pisane izjave o opozivu već 
koja predviđa da će se u slučaju opoziva darovanja primjenjivati odredbe o stjecanju bez osnove, i da je obdarenik dužan vratiti dar (čl.498. ZOO-a). Shodno tome, darovatelj nakon što je opozvao darovanje izjavom u zakonom propisanom obliku može tražiti sudskim putem povrat dara (ili naknadu njegove vrijednosti ako je nemoguć povrat) uz eventualno i prethodno postavljeni tužbeni zahtjev na utvrđenje da je prestao ugovor o darovanju opozivom, ukoliko isti ima pravni interes. Dakle, prema aktualnim odredbama ZOO-a nadležan sud (više) ne može opozvati ugovor o darovanju zbog grube nezahvalnosti, jer se predmetni ugovor opoziva izjavom samog darovatelja. ${ }^{21}$ Upravo je i u tome značajna razlika u odnosu na opoziv darovanja prema odredbama pravnih pravila OGZ-a, koji je zahtijevao da se podnosi konstutivna tužba ${ }^{22}$ tj. sud je taj koji je raskidao ugovor o darovanju zbog razloga zbog kojih se može opozvati (poreći) ugovor o darovanju prema pravnim pravilima OGZ-a. Shodno tome, prema aktualnim odredbama ZOO-a. Izostanak izjave o opozivu darovanja u zakonom propisanoj formi i na zakonom propisani način, dovodi do posebnog pravnog učinka da se smatra kako nikada nije došlo do opoziva darovanja. ${ }^{23}$ Dakle, prema ZOO-u izjava darovatelja o opozivu ugovora o darovanju ima konstutivan raskidan učinak ukoliko je dana na valjani raniji opisan način ${ }^{24}$.

Nadalje, razlika je u roku u kojem darovatelj može tražiti opoziv darovanja zbog grube nezahvalnosti. Prema OGZ-u isti je predviđao trogodišnji zastarni subjektivni rok dok je novi ZOO-a predvidio jednogodišnji subjektivni prekluzivni rok.

\footnotetext{
kada je daroprimatelj za nju saznao- a kada mu se ona dostavlja putem pošte preporučeno onda se smatra da je to dan predaje pošti..." Iz predmetnog citata može se zaključiti da samo sastavljanje izjave ne dovodi do prestanka ugovora već je potrebno da darovatelj poduzme aktivnu radnju kako bi sam obdarenik saznao da je opozvan ugovor o darovanju pri čemu slanje putem preporučeno poštom se smatra da je darovatelj ispunio svoj zakonsku obvezu upućivanja izjave o opozivu.

${ }_{21}$ Županijski sud u Varaždinu u odluci u predmetu posl.br. GŽ-5912/14-2 od dana 28.listopada 2015.godine navodi da: „.... Iz citiranih zakonskih odredbi proizlazi da se darovanje učinjeno nakon stupanja na snagu novog Zakona o obveznim odnosima (01. siječnja 2006.g.) valjano opoziva jedino pisanom izjavom upućenom obdareniku na kojoj potpis mora biti ovjeren od strane javnog bilježnika, a tužitelj niti ne tvrdi da bi ugovor opozvao na takav zakonom propisani način što nastavno znači da sud nije nadležan odlučivati o zahtjevu darovatelja za opoziv ugovora o darovanju sklopljenih nakon 01. siječnja 2006. g. pa je tužbu tužitelja u dijelu kojim traži opoziv ugovora o darovanju prvostupanjski sud koji sukladno čl. 16.st.1.ZPP-a po službenoj dužnosti pazi ide li rješavanje spora u sudsku nadležnost trebao već u fazi prethodnog ispitivanja tužbe odbaciti sukladno čl. 282. st. 1. ZPP-a..."

22 Vrhovni sud RH-a u odluci u predmetu posl.br. Rev-2800/1993-2 od dana 06.prosinca 1994.godine: „....Ugovor o darovanju može se opozvati ako je daroprimac pokazao grubu nezahvalnost prema darodavcu. Opoziv ugovora može se izvršiti posebnom konstitutivnom tužbom u parnici, a ne prigovorom. Prema tome sudovi se nisu ni trebali baviti pitanjem nezahvalnosti u ovoj parnici, koju je pokrenuo tužitelj radi isplate..."

${ }_{23}$ Županijski sud u Sisku u odluci u predmetu posl.br. GŽ 910/2014-7 od dana 24.kolovoza 2017.godine: „... Odredbom čl. 496. st. 1. ZOO izričito je propisano da se darovanje opoziva pisanom izjavom upućenom obdareniku, a st. 2. istog članka propisano je da potpis na izjavi mora biti ovjeren od strane javnog bilježnika... No, kako tužitelj predmetni ugovor o darovanju nije opozvao na način propisan čl. 496. ZOO, a obdarenik je sukladno čl. 498. st. 1. ZOO dužan vratiti stvar u slučaju opoziva to prema ocjeni ovog suda zahtjev tužitelja za uspostavom ranijeg zk. stanja brisanjem prava vlasništva tuženice na predmetnoj darovanoj nekretnini upisanog na osnovu ugovora o darovanju koji je na snazi, uz uknjižbu tog prava na tužitelja, nije osnovan..."

${ }_{24}$ Županijski sud u Splitu u odluci u predmetu posl.br. Gž-779/20-2 od dana 21.siječnja 2021.godine:, „... Izjava o opozivu darovanja ima konstitutivan raskidni učinak...Kako tužitelj predmetni ugovor o darovanju nije opozvao na način propisan člankom 496. ZOO/05, a obdarenik je sukladno članku 498. stavku 1.ZOO/05 dužan vratiti stvar tek u slučaju opoziva, to prema ocjeni ovog suda zahtjev tužitelja u dijelu za uspostavom ranijeg zemljišnoknjižnog stanja brisanjem prava vlasništva tuženika na predmetnim darovanim nekretninama upisanog na osnovu ugovora o darovanju kojije na snazi, nije osnovan..."
} 


\section{Gruba nezahvalnost prema pravnim pravilima OGZ-a}

Kao što je u više puta istaknuto u ovom radu, prema prijelaznim i završnim odredbama Zakona o obveznim odnosima za ugovorne odnose koje su nastali prije stupanja na snagu predmetnog Zakona mjerodavni su raniji propisi koji su se primjenjivali u tom razdoblju. Također ranije je navedeno, i da Zakon o obveznim odnosima iz 1978.godine nije sadržavao odredbe o ugovora o darovanju, već su za takve ugovorne odnose mjerodavna pravna pravila OGZ-a. U tom slučaju potrebno je navesti i što je predstavljao razlog radi opoziva darovanja zbog nezahvalnosti prema odredbi OGZ-a.

OGZ u paragrafu br. 948 govori o porećenju radi neharnosti te navodi da: „....Darovanje može se poreći, ako je obdarenik krivac kakve grube neharnosti prema svom dobročincu. Pod grubom neharnošću razumijeva se takva pozljeda tijela ili uvreda u poštenju, u slobodi ili u imovini, da se protiv uvredioca može postupati službeno ili na zahtijevanje uvrjeđenika po zakonu kaznenom..."

Predmetnu odredbu treba tumačiti u duhu današnjeg vremena tako da govorimo o pravu na sudski raskid darovanja zbog grube nezahvalnosti obdarenika prema darovatelju. ${ }^{25}$ Uvidom u citiranu odredbu vidljivo je da prije svega ponašanje obdarenika mora imati obilježja kaznenog djela. Međutim, nije nužno i da je obdarenik osuđen za kazneno djelo već je dovoljno da njegovo ponašanje sadrži obilježja kaznenog djela. ${ }^{26}$ Naravno, ukoliko dođe do kaznene osude, parnični sud koji vodi postupak opoziva darovanja vezan je za takvu kaznenu osudu. ${ }^{27}$ Predmetni paragraf OGZ-a ne navodi koja točno kaznena djela obdarenik mora počiniti, već govori o onim dobrima koje mogu biti povrijeđene kaznenim djelom i to život, čast, tijelo, slobodu i imovinu darovatelja. U tom slučaju parnični sud koji odlučuje o raskidu ugovora mora ocijeniti jesu li počinjenim djelom (koji predstavlja obilježja kaznenog djela) povrijeđena predmetna citirana dobra. Sporno je da li to kazneno djelo mora biti počinjeno sa namjerom ili nehajom. Uvidom u stav Vrhovnog suda Republike Hrvatske kroz sudsku praksu vidljivo je da je isti uglavnom zauzimao stav da je potrebno da se predmetno kazneno djelo počini sa namjerom ${ }^{28}$ što je u pravilu točno, jer svjesno i voljno postupanje da se počini kazneno djelo predstavlja u pravilu grublji oblik nemorala zbog čega je opravdano opozvati ugovor o darovanju. Međutim, to ne isključuje mogućnost i da neki nehajni oblik kaznenog djela može dovesti do takvog težeg oblika nemorala zbog kojeg bi bilo opravdano opozvati

\footnotetext{
${ }_{25}$ Vrhovni sud RH-a u odluci u predmetu posl.br. Rev 1167/04-2 od dana 07.rujna 2005.godine: „...Pri tome “poreći darovanje" treba, u duhu važećeg ugovornog prava, tumačiti pravom na raskid ugovora o darovanju...".

${ }^{26}$ Vrhovni sud RH u odluci u predmetu posl.br. Rev 80/08-4 od dana 02.prosinca 2008.godine: „...U konkretnom slučaju, utvrđeno ponašanje tuženika prema tužiteljici ima obilježja kaznenog djela, a nije nužno za opoziv darovanja da je do kaznenog progona prema tuženiku i došlo..."Vrhovni sud RH u odluci u predmetu posl.br. Rev 58/91-2 od dana 07.svibnja 1991.godine: „... Nije odlučno što u krivičnom postupku koji je vodjen protiv tuženice nije došlo do pravomoćne osudjujuće presude protiv nje, a koji prigovor stoga ova neosnovano ističe u reviziji..."

27 Članak 12.st.2. Zakona o parničnom postupku ("Službeni list SFRJ" br. 4/77., 36/77., 36/80., 6/80., 69/82., 43/82., 58/84., 74/87., 57/89., 20/90., 27/90., 35/91., "Narodne novine” br. 53/91., 91/92., 112/99., 129/00., 88/01., 117/03., 88/05., 2/07., 96/08., 84/08., 123/08., 57/11., 148/11. - službeni pročišćeni tekst, 25/13., 89/14., 70/19 u daljnjem tekstu: Zakon o parničnom postupku ili ZPP).

${ }^{28}$ Vrhovni sud Republike Hrvatske u odluci u predmet posl.br. Rev-1099/08 od dana 21.listopada 2010.godine: „.... Prema tome, nezahvalnost mora biti gruba u tolikoj mjeri da su njome ostvareni elementi umišljajnog izvršenja kaznenog djela, koje bi moglo predstavljati ozljedu tijela, uvredu poštenja, povredu slobode ili imovine darovatelja..." Takav stav Vrhovni sud zauzima u brojnim drugim odlukama primjerice posl.br. Rev-58/1991 od dana 02.svibnja 1991.godine, posl.br. Rev 1538/1992 od dana 20.listopada 1992.godine, posl.br. Rev 2544/1991-2 od dana 10.ožujka 1992.godine.
} 
ugovor o darovanju, a da li će takvo ponašanje dovesti do grube nezahvalnosti ovisi o okolnostima konkretnog slučaja. ${ }^{29} \mathrm{Na}$ isti način bi trebalo tumačiti i krug osoba prema kojima može biti počinjeno kazneno djelo od strane obdarenika. Naime, nije nužno da obdarenik počini kazneno djelo isključivo prema darovatelju, već isti može počiniti djelo i prema njemu bliskim osobama da to počinjenje djela toliko teško pogađa obdarenika da je opravdano da isti traži opoziv darovanja. ${ }^{30}$

Međutim, samo postojanje kaznenog djela ne znači automatizmom da postoji i razlog radi opoziva darovanja, već takva kaznena radnja mora (kumulativno) predstavljati i radnju koja po svom značenju predstavlja toliku grubu nezahvalnost da razumno opravdava opoziv darovanja. ${ }^{31}$

\section{Gruba nezahvalnost prema odredbi Zakona o obveznim odnosima}

Nakon što je prikazano poimanje grube nezahvalnosti prema odredbama pravnih pravila OGZ potrebno je i prikazati na koji način poima grubu nezahvalnost važeći Zakon o obveznim odnosima. Prema odredbi čl. 494. st.2. ZOO-a grubu nezahvalnost „....podrazumijeva da je obdarenik učinio prema darovatelju ili nekom od članova njegove uže obitelji djelo kažnjivo po kaznenim propisima ili se teže ogriješio o zakonom utvrđene dužnosti prema darovatelju ili članu njegove uže obitelji..."

Pregledom citirane odredbe jasno je vidljivo da je Zakonodavac otklonio nejasnoće koje su eventualno postojale oko toga da li je potrebno da se kazneno djelo počini sa namjerom ili lakšim stupnjem krivnje, kao i da li se djelo mora počiniti isključivo prema darovatelju. Prema zakonskoj odredbi, dovoljno je da predmetno djelo predstavlja kažnjivu radnju prema kaznenim propisima. Tako ako kazneni propisi i predviđaju da je nehajno ponašanje kažnjivo, ista radnja može predstavljati razlog radi opoziva darovanja. Međutim, to ne znači da je počinjenjem kaznenog djela opravdano automatizmom opozvati ugovor o darovanju, već je potrebno da takvo ponašanje (kazneno djelo) predstavlja krajnji oblik nezahvalnosti obdarenika prema darovatelju, da je razumno da se opozove ugovor. Nadalje, predmetna odredba je i izričito prošila krug osoba prema kojima može biti počinjeno djelo tako da navodi ne samo obdarenika već i njegove članove uže obitelji. Zakonska odredba ne daje definiciju članova uže obitelji već će sudska praksa definirati pojam uže obitelji.

\footnotetext{
${ }^{29}$ Stav Vrhovnog suda Republike Hrvatske u odluci u predmetu posl.br. Rev 631/08-2 od dana 28.siječnja 2009. godine: „... Pogrešan je pravni stav drugostupanjskog suda da bi opoziv ugovora o darovanju zbog nezahvalnosti opravdavalo jedino umišljajna povreda tijela, života, časti, slobode ili imovine darodavca, jer se opoziv darovanja može tražiti zbog svakog onog djela ili ponašanja koje po svojoj težini ili posljedicama na odnose među strankama razumno opravdava opoziv darovanja..."

30 Vrhovni sud Republike Hrvatske u odluci u predmetu posl.br. Rev 1014/1992-2 od dana 12.kolovoza 1992.godine: „...Prema usvojenoj sudskoj praksi ovog Vrhovnog suda gruba neharnost mora biti takva da ujedno predstavlja i krivično djelo ali tako krivično djelo učinjeno na štetu daroprimca ili njemu bliske osobe da na odnose daroprimca i darodavca ima takav značaj da razumno opravdava opoziv darovanja kako se to pravilno ističe u obrazloženjima nižestepenih presuda..." 31 Vrhovni sud RH u odluci u predmetu posl.br. Rev-454/03-2 od dana 06.listopada 2004.godine: „...radnje daroprimca prema darodavcu moraju imati obilježje kaznenog djela, te po svom značenju moraju razumno opravdavati opoziv darovanja, koji uvjeti moraju biti ispunjeni kumulativno..."Takav stav Vrhovni sud Republike Hrvatske je zauzeo u svojim brojnim drugim odlukama primjerice: u predmetima posl.br. Rev 1526/98-2, posl.br. Rev 816/10-2, posl. br. Rev 1099/08-2, posl.br. Rev 3205/94, posl.br. Rev 976/1994-2
} 
Bitna razlika pojma grube nezahvalnosti prema Zakonu obveznim odnosima u odnosu na poimanje grube nezahvalnosti prema pravnim pravilima OGZ-a jest i ta što prema Zakonu o obveznim odnosima nije nužno (tj. nije uvjet) da određeno ponašanje predstavlja obilježje kaznenog djela, već grubu nezahvalnost predstavlja i teže ogrješenje Zakonom utvrđene dužnosti prema darovatelju ili članu njegove uže obitelji.

Što bi predstavljalo teže ogrješenje Zakonom utvrđene dužnosti, zakon ne definira već je to pitanje sudske prakse koja će isto utvrditi o slučaja do slučaja. Očigledno je da zakonodavac stavio naglasak isključivo na zakonske dužnosti (obveze), a ne na ugovorne obveze. Shodno tome, ugovor o darovanju ne može se opozvati zbog grube nezahvalnosti ako primjerice obdarenik nije ispunio obvezu iz tog ugovora o darovanju, ili nekog drugog njihovog ugovornog odnosa. ${ }^{32}$ Međutim, to ne znači da svaka povreda neke zakonske dužnosti obdareniku prema darovatelju ili njegovom članu uže obitelj predstavlja razlog za opoziv darovanja. Upravo je u okviru te odredbe i stavljen na naglasak na „težem ogrješenju“ koje dovodi do takvog oblika nemoralnog i nezahvalnog ponašanja da je razumno opozvati ugovor o darovanju a što opet ovisi okolnostima konkretnog slučaja.

U okviru tog težeg ogrješenja zakonom utvrđene dužnosti često se u praksi može postaviti i pitanje je li prevara bračnog druga može predstavljati teže ogrješenje zakonom utvrđene dužnosti zbog kojeg je opravdano opozvati ugovor? Obiteljski zakon (čl.31.) zaista i predviđa pravo i obvezu bračnih drugova da budu vjerni u braku, kao i da se isti moraju međusobno poštivati, ali isti ne predviđa nikakve sankcije. Upravo zbog takvog ne postojanja sankcija sudska praksa je za sada zauzela stav da prevara bračnog druga, ako je i postojala ne predstavlja teže ogrješenje zakonom utvrđenih obveza, zbog kojih bi bilo opravdano opozvati ugovor o darovanju. ${ }^{33} \mathrm{Na}$ jednak način bi trebalo tumačiti i postojanje primjerice ljubavne veze obdarenika i (izvan)bračnog partnera darovatelja, jer obdarenik pored činjenice da on nije taj koji se ogriješio o zakonom utvrđeni dužnosti (jer nije u braku sa darovateljem) isti nije činio (vjerojatno) predmetne radnje sa ciljem da nanese štetu darovatelju, već su plod nekih životnih (ne)prilika. ${ }^{34}$

\footnotetext{
32 Uporište autora u takvom stavu može se pronaći i u ranijim odlukama sudova Republike Hrvatske koje su doduše primjenjivali odredbe ranijih pravnih pravila ali su isticali da opoziv za darovanje ne može predstavljati povredu neke ugovorne obveze koju je darovatelj očekivao jer je ugovor o darovanju besplatni pravni posao, pa tako Županijski sud u Varaždinu, u odluci u predmetu posl.br. GŽ 911/03-2 od dana 06.kolovoza 2003.godine navodi da: „....Motivi darovatelja za sklapanje ugovora o darovanju i njegova očekivanja u ispunjenju određenih obveza ili određenog ponašanja daroprimca nisu ni od kakvog značaja u odnosu na ocjenu pretpostavki za opoziv darovanja iz razloga što je darovni ugovor besplatni pravni posao..."

33 Županijski sud u Varaždinu, stalna Služba u Koprivnici, u odluci u predmetu posl.br. GŽ- 532/18-2 od dana 11.siječnja 2018.godine: „....Sama nevjera, odnosno stupanje tuženice u preljubnički odnos s drugim muškarcem, kada bi i bila dokazana, a u ovom slučaju ostaje na razini pretpostavki, jer čvrsti dokaza nema, po ocjeni ovog suda ne predstavalja grubu nezahvalnost u smislu odredbe čl. 494.st.2. ZOO-a, iako vrijeđa emocionalnu stranu tužitelja i u svakom slučaju narušava odnos između tužitelja i tuženice....", Odluka Vrhovnog suda Republike Hrvatske u predmetu posl.br. Rev 2915/1993-2 od dana 26.listopada 1994.godine: „... Predmet ovoga spora je zahtjev tužitelja da se spomenuti ugovor opozove radi neharnosti tužene, konkretno preljuba...Stoga preljub u utvrđenim okolnostima konkretnog slučaja, sve $i$ da je počinjen, ne predstavlja grubu neharnost..."

34 Županijski sud u Puli u odluci u predmetu posl.br. GŽ-88/2016-4 od dana 04.kolovoza 2015.godine: „...Ako je, doista, i postojala ljubavna veza između bivše supruge tužitelja i tuženika nije, ili barem to nije dokazano, uspostavljena sa namjerom da se tužitelju nanese šteta već bi bila plod aktualnih životnih prilika pa to onda ne može biti valjani osnov za opoziv predmetnog ugovora..."
} 


\section{Nepristojno ponašanje ili gruba nezahvalnost?}

Uvidom u ranije navedeno pravno poimanje opoziva darovanja prema OGZ-u i ZOO-a vidljiva je razlika da je prema OGZ-u postojanje radnje koja sadrži obilježja kaznenog djela uvjet, dok je prema ZOO-u takva radnja jedna od mogućnosti zbog kojih se može opozvati ugovor o darovanju zbog grube nezahvalnosti. Međutim, ono što im je zajedničko je to da počinjenje kaznenog djela ne dovodi automatizmom do postojanja razloga radi opoziva darovanja, već je potrebno ispitati i da li takva kaznena radnja opravdava da se opozove ugovor o darovanju.

Naime, predmetna radnja mora biti toliko gruba da je u konkretnom slučaju razumno opozvati ugovor o darovanju. Ono što je pitanje jest da li je uopće moguće standardizirati takva gruba ponašanja da bi svaki primjenjivač mogao znati da ukoliko dođe do određenog nemoralnog ponašanja da je siguran da takva radnja u konkretnom slučaju predstavlja razlog radi opoziva upravo zato što se istovjetna radnja dogodila u nekom drugom slučaju, a koja je dovela do opoziva?

Odgovor je negativan, jer svako grubo ponašanje je faktično pitanje koje ovisi o okolnostima konkretnog slučaja. ${ }^{35}$ Kako cijeniti nešto kao grubu nezahvalnost (od blažeg nepristojnog ponašanja) primjerice je dao Vrhovni sud Republike Hrvatske u odluci u predmetu posl. br. Rev 1260/93-2 od dana 26.siječnja 1995.godine kada je naveo da je u svakom konkretnom slučaju potrebno ocijeniti težinu i posljedicu na odnose među strankama, okolnostima pod kojima je počinjeno da bi se moglo ocijeniti je li razumno to ponašanje uzeti kao takav stupanj neharnosti koji opravdava raskid odnosno utvrđenje da je opozvan ugovora o darovanju. Prema mišljenju autora na jednak način bi se trebalo pristupiti i prilikom primjene odredbe ZOO-a o opozivu darovanja, jer ne postoji priroda razlike u opozivu darovanja zbog grube nezahvalnosti prema OGZ-u i ZOO-u kada su tim radnjama ostvarena obilježja kaznenog djela.

Nadalje, Vrhovni sud Republike Hrvatske zauzeo je stav da ocjena suda o postojanju grube nezahvalnosti ovisi o okolnostima konkretnog slučaja, u toj mjeri da nije dopustio podnošenje revizije za osiguranje jedinstvene primjene prava i ravnopravnosti u primjeni, jer smatra da pitanje grube zahvalnosti i njenih određenih pitanja ponašanja nije moguće standardizirati kroz sudsku praksu ${ }^{36}$.

Ono što bi se moglo standardizirati iz praske sudova Republike Hrvatske (ma da to nije nužan slučaj, jer opet sve ovisi o okolnostima konkretnog slučaja) jesu ona neprimjerena ponašanja koja iako su nemoralna ne predstavljaju takvu grubost da je zbog istih opravdano opozvati ugovor o darovanju.

\footnotetext{
35 Vrhovni sud Republike Hrvatske u odluci u predmetu posl.br. Rev 2054/1990-2 od dana 08.siječnja 1991.godine: „...Međutim, postojanje neharnosti kao razloga za raskid ugovora o darovanju je faktično pitanje. Svako ponašanje daroprimca prema darodavcu za koje je propisana krivična odgovornost sama po sebi ne mora uvijek predstavljati $i$ razlog za raskid ugovora o darovanju..."

${ }^{36}$ Vrhovni sud Republike Hrvatske u odluci u predmetu posl.br. Rev 1843/12-2 od dana 16.ožujka 2016.godine primjenjujući tada važeći Zakon o parničnom postupku (Službeni list SFRJ" br. 4/77., 36/77., 36/80., 6/80., 69/82., 43/82., 58/84., 74/87., 57/89., 20/90., 27/90., 35/91., “Narodne novine" br. 53/91., 91/92., 112/99., 129/00., 88/01., 117/03., 88/05., 2/07., 96/08., 84/08., 123/08., 57/11 u daljnjem tekstu ZPP 2011) je sukladno odredbi čl.392.b.st.2. ZPP 2011 odbacio reviziju tužitelja podnesenu prema čl. 382.st.2.ZPP-a 2011 (tzv. izvanrednu reviziju) a iz razloga što se prema mišljenju Vrhovnog suda Republike Hrvatske zbog prirode primjeni odredbe o gruboj nezahvalnosti i poimanju takve nezahvalnosti ne može se niti postaviti pitanje koje bi bilo usmjereno na ujednačavanje sudske prakse koje bi dovelo da u jednakosti u primjerni upravo iz razloga što je pitanje grube nezahvalnosti faktično pitanje.
} 
Primjerice, pojedini verbalni incidenti bi se mogli okvalificirati kao nekulturno ponašanje, a ne kao gruba nezahvalnost obdarenika ${ }^{37}$. Verbalni incidenti tj. grube riječi i psovke koje obdarenik izrekne darovatelju ili njegovim članovima obitelji ne ovise samo o težini tih psovki i uvreda, već i o drugim okolnostima. Tako primjerice, ako je obdarenik darovatelju koji boluje od karcinoma izrekao „neka crkne rakašica“38 će prije opravdati da se takvo ponašanje označi kao grubu nezahvalnost, nego da je isti izrekao darovatelju koji nema takvih problema. Dakle, bitno je koliko se takve uvrede reflektiraju na odnos između stranaka (uzimajući sve okolnosti slučajeva pa tako i primjerice da li je darovatelj bolestan, starije životne dobi, itd.) da je upravo zbog takvog ponašanje razumno opravdati opoziv darovanja.

Nadalje, izostanak komunikacije između darovatelja i obdarenika ne bi trebao predstavljati grubu nezahvalnosti ${ }^{39}$ pogotovo ukoliko su isti nakon nekog incidenta nastavili normalno komunicirati ${ }^{40}$. U svakom slučaju nema razloga radi opoziva darovanja ako je obdarenik oprostio takav incident. ${ }^{41}$ Isto tako, izostanak nekog fizičkog kontakta tj. posjećivanje darovatelja također samo po sebi ne bi predstavljao razlog grube nezahvalnosti zbog kojeg bi trebalo opravdano otkazati ugovor o darovanju. ${ }^{42}$ Opet sve ovisi okolnostima konkretnog slučaja, pa primjerice izostanak kontakta, posjećivanje i briga o teškom bolesnom darovatelju od strane obdarenika koji nema mogućnosti da se sam o sebi brine, bi u nekom konkretnom slučaju mogao dovesti do ocjene takvog ponašanja kao grubo nezahvalnog, ako je isti obdarenik imao zakonsku obvezu da se stara o darovatelju ${ }^{43}$.

Nadalje, na jednak način bi trebalo tumačiti i pitanje težeg ogrješenja zakonskih obveza, jer što bi predstavljalo teže ogrješenje zakonskih obveza ovisi o okolnostima konkretnog slučaja. $\mathrm{U}$ predmetnom radu je istaknuto da su sudovi u pojedinim predmetima zauzeli stav

\footnotetext{
37 Vrhovni sud Republike Hrvatske u odluci u predmetu posl.br. Rev 169/07 od dana 29.travnja 2009.godine „...Razlog za opoziv nižestupanjski sudovi nalaze u postupanju tuženika koji je 1. tužiteljici M. F. nakon što mu je darovala dio svojih nekretnina jednom prilikom uskratio dati ključ od kuće ostale dvojice braće, odnosno sestre, na grobnom mjestu jednom počupao cvijeće i pred sada pokojnom majkom rekao joj da nema tu što tražiti. Drugotužiteljici K. Z. koja mu je također darovala dio svojih nekretnina je prilikom izvođenja građevinskih radova na kući rekao njoj i bratu I. „što su došli u njegovo dvorište", da je bratu psovao, a njoj da je "odmjerio rukom".. „Ovaj sud ne može se složiti sa ocjenom nižestupanjskih sudova da ponašanje tuženika prema sestrama predstavlja grubu nezahvalnost koja bi opravdavala opoziv darovanja. Ponašanje tuženika nije lijepo, ali u konkretnom slučaju ne radi se o gruboj nezahvalnosti prema tužiteljicama, već o incidentima koji graniče sa nekulturnim ponašanjem. Zato u ovom konkretnom slučaju ponašanje tuženika prema tužiteljicama ne predstavlja tako grubu nezahvalnost koja bi po svom značenju razumno opravdala opoziv ugovora o darovanju.."

38 Županijski sud u Bjelovaru, u odluci u predmetu posl.br. Gž- 1318/07, od 13.prosinca 2007.godine „...Radi se o nezahvalnosti i to gruboj kada obdarenik darovateljici, inače bolesnoj od karcinoma, govori "neka crkne" ",rakašica" itd., koja opravdava opoziv ugovora o darovanju..."

39 Županijski sud u Slavonskom brodu u odluci u predmetu posl.br. GŽ-185/13-2 od dana 31.ožujka 2014.godine: „... Okolnost što tuženica ne razgovara s tužiteljem i što ga nije pozvala na svadbu ne predstavlja grubu nezahvalnost kako se ona podrazumijeva prema čl. 494. st. 2. ZOO..."

40 Odluka Vrhovnog suda Republike Hrvatske u predmetu posl.br. Rev 2385/99-2 od dana 14.siječnja 2003.godine: „... po ocjeni ovog suda, izjava tuženice dana tijekom svađe između stranaka, da će tuženica dati ubiti tužiteljicu, a pored činjenice da zbog toga nije došlo do poremećaja odnosa između stranaka, opravdava zaključak da se nije radilo o ozbiljnoj prijetnji i kaznenom djelu koje bi razumno opravdavalo opoziv darovanja iz razloga grube nezahvalnosti, pa je stoga materijalno pravo pravilno primijenjeno kada je tužbeni zahtjev odbijen kao neosnovan..."

${ }^{41}$ Paragraf 949 OGZ odnosno čl.494. st.4. ZOO-a

42 Odluka Vrhovnog suda Republike Hrvatske u predmetu posl.br. Rev 453/02-02 od dana 25.ožujka 1998.godine: „...Prema shvaćanju ovog revizijskog suda, činjenica da tuženik (daroprimatelj) nije posjećivao tužitelja (darovatelja) dok se nalazio u bolnici, i poslije kada je izašao iz bolnice, iako im se kuće u kojima stanuju, nalaze blizu, sama za sebe ne predstavlja opravdan razlog za opoziv darovanja u smislu pravnog pravila paragrafa 948. OGZ-a..."

43 Odluka Vrhovnog suda Republike Hrvatske u predmetu posl.br. Rev 575/09-2 od 4.lipnja 1998.godine
} 
da prijevara bračnog druga ne predstavlja teže ogrješenje zakonske obveze zbog izostanka sankcije u posebnom zakonu. Međutim, čak i da postoji neka zakonska sankcija za takvo postupanje to ne bi značilo da postoji razlog radi opoziva darovanja jer ocjena takvog postupanja ovisi okolnostima konkretnog slučaja. U svakom slučaju na darovatelju je da dokaže postojanje okolnosti koje su u njegovom slučaju opravdali da se opozove ugovor o darovanju. ${ }^{44}$

\section{Zaključak}

Ugovor o darovanju zbog svog besplatnog pravnog karaktera predstavlja iznimku u današnjim ugovorno pravnim odnosima jer stvara osnovu za prijenos imovine bez ikakve protuusluge. Upravo zbog te svoje specifičnost predviđena je mogućnost prestanka punovažnog $\mathrm{i}$ ispunjenog ugovora o darovanju putem instituta opoziva darovanja. Opoziv darovanja zbog grube nezahvalnosti polazi od zahtjeva pravičnost da je nepravično "ostaviti" ugovor na snazi, ako je obdarenik svojim ponašanjem zaboravio učinjeno darovanje, te se ponašao na krajnje grub nezahvalan način.

Kroz predmetni rad vidljivo je da se institut opoziva zbog grube nezahvalnosti u Republici Hrvatskoj mijenjao tijekom svoje pravne povijesti. Početno se prema pravnim pravilima OGZ-a tražilo da predmetna radnja sadrži obilježja kaznenog djela, dok je sada prema ZOO-a samo jedna od mogućnosti na koji se obdarenik može grubo ponašati a zbog kojeg se može opozvati ugovor o darovanju. Međutim, ono što je zajedničko i OGZ-u i ZOO prema sudskoj praksi je da samo ostvarivanje radnje koja sadrži obilježja kaznenog djela ne znači automatizmom da je ostvaren razlog radi opoziva darovanja. Upravo je sudska praksa tijekom svoje povijesti izričito navela da je potrebno da takva kaznena radnja predstavlja i krajnje grubu radnju zbog čega je opravdano otkazati ugovor o darovanju. Sudska praksa je i izričito navela i da takva gruba radnja u cijelosti ovisi o okolnostima slučaja, te da se ne mogu standardizirati određeni oblici ponašanja koji bi automatizmom dovele do prestanka ugovora o darovanju opozivom. Pregledom sudske prakse može se i vidjeti da su na određeni način standardizirani razlozi koji predstavljaju nepristojno ponašanje, ali ne i razlog radi opoziv darovanja. Međutim, to opet ovisi o okolnostima konkretnog slučaja, tako da i pojedini ekscesi koji u većini slučajeva ne predstavljaju razlog radi opoziva darovanja, mogu dovesti u nekom predmetu do opoziva darovanja.

lako je Zakon o obveznim odnosima suzio razloge zbog kojeg se može opozvati ugovor o darovanju isti je i proširio pojam same grube nezahvalnosti i to na način i da se gruba nezahvalnost može ostvariti težom povredom zakonskih obveza. Međutim, i to teže ogrješenje zakonskih obveza je također faktično pitanje koje ovisi o okolnostima konkretnog slučaja. Za sada je vidljivo da iz sudske prakse proizlazi da prijevara bračnog druga ne predstavlja razlog radi opoziv darovanja. Obrazloženje odluka koji su citirani u predmetnom radu počivaju na činjenici da iako je predviđena zakonska obveza na međusobno poštivanje i vjernost da takva obveza ne povlači sa sobom nikakve sankcije u obiteljsko pravnim odnosima, pa shodno tome prema mišljenju sudske prakse, ne stvara sankcije i u građansko pravnim odnosima (bivših) (izvan)bračnih partnera radi prestanka ugovora o darovanju.

\footnotetext{
44 Županijski sud u Rijeci u odluci u predmetu posl.br. GŽ-1819/2018 od dana 06.ožujka 2019.godine: „....Budući da tužiteljica, na kojoj je teret dokaza prema čl. 7. st. 1., čl. 219. st. 1. i čl. 299. st. 1. ZPP-a, nije dokazala razloge za opoziv ugovora o darovanju zbog nezahvalnosti tužene, prvostupanjski je sud pravilnom primjenom čl. 494. st. 1. i 2. ZOO/05 odbio tužbeni zahtjev tužiteljice..."
} 


\section{LITERATURA}

1. Belanić L., Gorenc V., Kačer H., Momčinović H., Slakoper Z., Vukmir B. (2012), Obvezno pravo, posebni dio l., pojedini ugovori, Novi informator, Zagreb

2. Crnić I.(2002), Zakon o obveznim odnosima s opsežnom sudskom praksom, Organizator, Zagreb

3. Klarić P., Vedriš M.(2009), Građansko pravo, Narodne novine, Zagreb,

4. Pravni leksikon(2007), Leksikografsko društvo Miroslava Krleže, Zagreb,

5. Odluka Vrhovnog suda Republike Hrvatske u predmetu posl.br. Rev-1259/90-2, od dana 10. listopada 1990. godine (preuzeto sa www.vsrh.hr, dan pristupa 26.05.2021.god.)

6. Odluka Vrhovnog suda Republike Hrvatske u predmetu posl. br. Rev-x 737/11-2 od dana 04. rujna 2012. godine(preuzeto sa www.vsrh.hr, dan pristupa 26.05.2021. god.)

7. Odluka Županijskog suda u Bjelovaru u predmetu posl.br. Gž-2391/2012, od dana 6. veljače 2014. godine (preuzeto sa www.iusinfo.hr, dan pristupa 26.05.2021.god.)

8. Odluka Županijskog suda u Varaždinu u predmetu posl.br. GŽ-5912/14-2 od dana 28.listopada 2015. godine(preuzeto sa www.iusinfo.hr, dan pristupa 26.05.2021.god.)

9. Odluka Vrhovnog sud RH-a u odluci u predmetu posl.br. Rev-2800/1993-2 od dana 06.prosinca 1994. godine (preuzeto sa www.vsrh.hr, dan pristupa 26.05.2021.god.)

10. Odluka Županijskog suda u Sisku u predmetu posl.br. GŽ 910/2014-7 od dana 24. kolovoza 2017. godine (preuzeto sa www.vsrh.hr, dan pristupa 26.05.2021.god.)

11. Odluka Vrhovnog suda RH-a u predmetu posl.br. Rev 1167/04-2 od dana 07. rujna 2005. godine (preuzeto sa www.vsrh.hr, dan pristupa 26.05.2021.god.)

12. Odluka Vrhovnog suda RH-a u predmetu posl.br. Rev 80/08-4 od dana 02. prosinca 2008. godine (preuzeto sa www.vsrh.hr, dan pristupa 26.05.2021.god.)

13. Odluka Vrhovnog suda RH-a u predmetu posl.br. Rev 58/91-2 od dana 07. svibnja 1991. godine (preuzeto sa www.vsrh.hr, dan pristupa 26.05.2021.god.)

14. Odluka Vrhovnog sud RH-a u predmet posl.br. Rev-1099/08 od dana 21. listopada 2010. godine (preuzeto sa www.vsrh.hr, dan pristupa 26.05.2021.god.)

15. Odluka Vrhovnog suda RH -a u predmetu posl.br. Rev-58/1991 od dana 02. svibnja 1991. godine, (preuzeto sa www.vsrh.hr, dan pristupa 26.05.2021.god.)

16. Odluka Vrhovnog suda RH -a u predmetu posl.br. Rev 1538/1992 od dana 20. listopada 1992.godine, (preuzeto sa www.vsrh.hr, dan pristupa 26.05.2021.god.)

17. Odluka Vrhovnog suda RH -a u predmetu posl.br. Rev 2544/1991-2 od dana 10. ožujka 1992.godine, (preuzeto sa www.vsrh.hr, dan pristupa 26.05.2021.god.)

18. Odluka Vrhovnog suda RH-a u predmetu posl.br. Rev 631/08-2 od dana 28. siječnja 2009. godine, (preuzeto sa www.vsrh.hr, dan pristupa 26.05.2021.god.)

19. Odluka Vrhovnog sud Republike Hrvatske u predmetu posl.br. Rev 1014/1992-2 od dana 12. kolovoza 1992.godine, (preuzeto sa www.vsrh.hr, dan pristupa 26.05.2021.god.)

20. Odluka Vrhovnog suda RH-a u predmetu posl.br. Rev-454/03-2 od dana 06. listopada 2004. godine, (preuzeto sa www.vsrh.hr, dan pristupa 26.05.2021.god.)

21. Odluka Županijskog suda u Varaždinu u predmetu posl.br. GŽ 911/03-2 od dana 06. kolovoza 2003. godine(preuzeto sa www.vsrh.hr, dan pristupa 26.05.2021. god.) 
22. Odluka Županijskog suda u Varaždinu, stalna Služba u Koprivnici, u predmetu posl.br. GŽ- 532/18-2 od dana 11. siječnja 2018. godine(preuzeto sa www.vsrh.hr, dan pristupa 26.05.2021. god.)

23. Odluka Vrhovnog suda RH-a u predmetu posl.br. Rev 2915/1993-2 od dana 26. listopada 1994. godine (preuzeto sa www.vsrh.hr, dan pristupa 26.05.2021. god.)

24. Odluka Županijskog suda u Puli u predmetu posl.br. GŽ-88/2016-4 od dana 04.kolovoza 2015. godine (preuzeto sa www.vsrh.hr, dan pristupa 26.05.2021.god.)

25. Odluka Vrhovnog suda RH-a u predmetu posl.br. Rev 1260/93-2 od dana 26. siječnja 1995.godine (preuzeto sa www.vsrh.hr, dan pristupa 26.05.2021. god.)

26. Odluka Vrhovnog suda RH-a u predmetu posl.br. Rev 2054/1990-2 od dana 08.siječnja 1991. godine (preuzeto sa www.vsrh.hr, dan pristupa 26.05.2021.god.)

27. Odluka Vrhovnog sud RH-a u predmetu posl.br. Rev 1843/12-2 od dana 16.ožujka 2016. godine(preuzeto sa www.vsrh.hr, dan pristupa 26.05.2021. god.)

28. Odluka Vrhovnog suda RH-a u predmetu posl.br. Rev 169/07-2 od dana 29.travnja 2009. godine (preuzeto sa www.vsrh.hr, dan pristupa 26.05.2021. god.)

29. Odluka Županijskog suda u Bjelovaru u predmetu posl.br. Gž- 1318/07-2, od 13. prosinca 2007. godine (preuzeto sa www.vsrh.hr, dan pristupa 26.05.2021. god.)

30. Odluka Vrhovnog suda RH-a u predmetu posl.br. Rev 2385/99-2 od dana 14. siječnja 2003. godine (preuzeto sa www.vsrh.hr, dan pristupa 26.05.2021.god.)

31. Odluka Vrhovnog suda RH-a u predmetu posl.br. Rev 453/02-02 od dana 25. ožujka 1998. godine (preuzeto sa www.vsrh.hr, dan pristupa 26.05.2021.god.)

32. Odluka Vrhovnog suda RH-a u predmetu posl.br. Rev 575/09-2 od 4. lipnja 1998.godine (preuzeto sa www.vsrh.hr, dan pristupa 26.05.2021.god.)

33. Odluka Županijskog suda u Rijeci u predmetu posl.br. GŽ-1819/2018 od dana 06. ožujka 2019. godine (preuzeto sa www.iusinfo.hr, dan pristupa 26.05.2021.god.)

34. Odluka Vrhovnog suda Republike Hrvatske u predmetu posl.br. Rev 816/10-2 od dana 27.lipnja 2012.godine (preuzeto sa www.vsrh.hr, dan pristupa 18.lipnja 2021.god.)

35. Odluka Županijskog suda u Splitu u predmetu posl.br. Gž-779/20-2 od dana 21. siječnja 2021. godine(preuzeto sa www.vsrh.hr, dan pristupa 18. lipnja 2021. god.)

\section{Summary}

\section{GROS INGRATITUDE AS A REASON OF REVOKING GIFTS}

Contracts that do not contain any shortcomings, and are fully fulfilled, in practice can rarely be terminated, all because of the civil principle that the contract is a statutory relationship between the parties. The gift contract is an exception, because it can be terminated through the institute of revocation of the gift, although it does not contain any defect, and is fully fulfilled. The gratuitousness of the gift contract is the reason why the legislator enables the termination of the fulfilled and valid gift contract. The Law on Obligations recognizes two reasons for revocation based either on the fact that the material circumstances on the part of the donor subsequently changed so much that the material existence of the 
donor is endangered, or on the fact that the other party is guilty of terminating the contract. The guilt of the other party or the donee does not refer to the guilt regarding the content of the gift contract and its fulfillment, because the contract is duly fulfilled. It is moral that the donee is grateful for the gift made, and that he does not take actions towards the donor that would lead to a significant disruption of mutual relations. However, the same donee forgets his "moral obligation", and after the gift is made, he begins to behave in a rude and immoral way towards the donor. That is why it is possible for the donor to revoke the donation contract through the institute due to gross ingratitude, which requires the fairness, even though the contract is fulfilled, because it is immoral for such a donee to keep what he received for free from the donor. The aim of this paper is to develop the concept of revocation of gifts due to gross ingratitude under the provisions of the current Law on Obligations. The present paper will also elaborate the notion of gross ingratitude according to the legal rules of OGZ, all considering that the same rules are (still) applicable to those gift contractual relations that arose before the entry into force of the current Law on Obligations.

Keywords: deed of gift, revocation of donation, gross ingratitude. 